\title{
Contents, Volume 2 (1991)
}

Biström, O.: First record of Chrysomela vigintipunctata from Finland (Coleoptera, Chrysomelidae) ........... 18

Biström, O., Franciscolo, M. E. \& Sanfilippo, N.: Yolina tiwaiensis Franciscolo \& Sanfilippo, 1990, junior synonym of Yolina libera Biström, 1987 (Coleoptera, Dytiscidae) 52

Biström, O., Silfverberg, H. \& Rutanen, I.: Abundance and distribution of coprophilous Histerini (Histeridae) and Onthophagus and Aphodius (Scarabaeidae) in Finland (Coleoptera)

53

Chvála, M.: Empididae (Diptera) of Finland: The Empis subgenera Empis and Coptophlebia ....................... 79

Clayhills, T.: The distribution and habitat of Stenus (Hemistenus) audax J. Sahlberg 1900 (Coleoptera, Staphylinidae) in Finland .. 25

Franciscolo, M. E.: see Biström, O., Franciscolo, M. E. \& Sanfilippo, N. 52

Gordeeva, E. W.: see Niemi, R. \& Gordeeva, E. W. .... 45

Hippa, H. \& Vilkamaa, P.: The genus Prosciara Frey (Diptera, Sciaridae) 113

Hirvenoja, M. \& Michailova, P.: The karyotype, morphology and ecology of Glyptotendipes aequalis Kieffer (Diptera, Chironomidae) ......................................... 87

Huldén, L.: see Pekkarinen, A. \& Huldén, L. ............. 179

Jansson, A.: Distribution and dispersal of Urophora cardui (Diptera, Tephritidae) in Finland 1985-1991 ...... 211

Jaros, J.: see Spitzer, K., Jaros, J. \& Svensson, I. ........ 33

Jussila, R.: Description of the male of Campodorus hyperboreus (Holmgren, 1855) (Ichneumonidae, Hymenoptera).....

43

Jussila, R.: Ichneumonidae new to Finland (Hymenoptera). I. 37

Kerppola, S.: Records of Microlepidoptera from Finland 1989 (Lepidoptera) .................................................. 7

Kononenko, V. S.: see Mikkola, K., Lafontaine, J. D. \& Kononenko, V. S. 157

Koponen, M.: Contributions to the knowledge of Braconidae of Finland (Hymenoptera) 193

Kuussaari, M.: see Väisänen, R., Somerma, P., Kuussaari, M. \& Nieminen, M. ............................................... 27

Lafontaine, J. D.: see Mikkola, K., Lafontaine, J. D. \& Kononenko, V.S. 157

Leppänen, P.: see Tomminen, J. \& Leppänen, P. ......... 49

Michailova, P.: see Hirvenoja, M. \& Michailova, P. ... 87
Mikkola, K., Lafontaine, J. D. \& Kononenko, V. S.: Zoogeography of the Holarctic species of the Noctuidae (Lepidoptera): importance of the Beringian refuge ......... 157

Niemi, R. \& Gordeeva, E. W.: Machuella hippy sp. n. (Acarina, Oribatida, Oppiidae) from Austria ......... 45

Nieminen, M.: see Väisänen, R., Somerma, P., Kuussaari, M. \& Nieminen, M. ........................................... 27

Pekkarinen, A. \& Huldén, L.: Distribution and phenology of the Ancistrocerus and Symmorphus species in eastern Fennoscandia (Hymenoptera, Eumenidae) .... 179

Rassi, P.. see Rutanen, I. \& Rassi, P. ........................... 23

Rutanen, I. \& Rassi, P.: Coelambus polonicus (Aube) and C. parallelogrammus (Ahrens) new to the Finnish fauna (Coleoptera, Dytiscidae) ............................... 23

Rutanen, I.: see Biström, O., Silfverberg, H. \& Rutanen, I. ... 53

Sanfilippo, N.: see Biström, O., Franciscolo, M. E. \& Sanfilippo, N. ...................................................... 52

Seifert, B.: Formica nigricans Emery, 1908 - an ecomorph of Formica pratensis Retzius, 1783 (Hymenoptera, Formicidae) 217

Silfverberg, H.: Changes 1986-1990 in the list of Finnish insects

.. 9

Silfverberg, H.: Nomenclatorial corrections in North European Coleoptera ...................................................... 21

Silfverberg, H.: see Biström, O., Silfverberg, H. \& Rutanen, I............................................................ 53

Somerma, P.: see Väisänen, R., Somerma, P., Kuussaari, M. \& Nieminen, M. ............................................ 27

Spitzer, K., Jaros, J. \& Svensson, I.: Geographical variation in food plant selection of Eupithecia gelidata Möschler, 1860 (Lepidoptera, Geometridae) ......... 33

Svensson, I.: see Spitzer, K., Jaros, J. \& Svensson, I. .. 33

Tomminen, J. \& Leppänen, P.: The male genitalia of $M o-$ nochamus sutor (L.), M. galloprovincialis (Olivier) and M. urussovi (Fischer von Waldheim) (Coleoptera, Cerambycidae) .............................................................. 49

Uusitalo, M.: Aphelacarus acarinus (Berlese) new to Finland (Acari, Oribatei) 47

Väisänen, R., Somerma, P., Kuussaari, M. \& Nieminen, M.: Bryodema tuberculata and Psophus stridulus in southwestern Finland (Saltatoria, Acrididae) ......... 27

Vazquez, X. A.: Redescription of Chrysanthia maroccana Lindberg, 1932 (Coleoptera, Oedemeridae) ........... 19 
Viitasaari, M. \& Zinovjev, A. G.: Taxonus zhelochovtsevi sp. n. and Apethymus parallelus (Eversmann, 1847) from the Soviet Far East (Hymenoptera, Tenthredinidae) 175

Viitasaari, M.: see Vikberg, V. \& Viitasaari, M. ......... 67

Vikberg, V. \& Viitasaari, M.: Trichiosoma nanae sp. n., a monophag on Betula nana from Finland (Hymenoptera, Cimbicidae) 67

Vilkamaa, P.: see Hippa, H. \& Vilkamaa, P. ............. 113 Wülker, W. F.: Chironomus fraternus sp. n. and C. beljaninae sp. n., sympatric sister species of the aberratus group in Fennoscandian reservoirs ...

Zinovjev, A. G.: see Viitasaari, M. \& Zinovjev, A. G.

\section{Short reports}

Chvála, M. \& Biström, O.: Bicellaria austriaca Tuomikoski, new for the Finnish fauna (Diptera, Hybotidae)

Clayhills, T.: Anidorus nigrinus (Germar) new to the Finnish fauna (Coleoptera, Aderidae)

Clayhills, T.: Euryalea pulcherrima Bernhauer new to the Finnish fauna (Coleoptera, Staphylinidae) ............... 2

Clayhills, T.: Psammocus bipunctatus (Fabricius) new to the Finnish fauna (Coleoptera, Cucujidae) ............... 3

Deletions from the fauna of Finland .............................. 5

Faunistic rarities ................................................................. 6

Kaila, L.: Orthosia munda (D. \& Schiff.) new to the Finnish fauna (Lepidoptera, Noctuidae)

Kangas, E.: Gyrophaena rugipennis Mulsant \& Rey new to the Finnish fauna (Coleoptera, Staphylinidae) ..... 2

Kangas, E.: The Galerucella (Hydrogaleruca) species in Finland (Coleoptera, Chrysomelidae) ....................... 2

New provincial records ................................................... 5

Rutanen, I.: Atheta (Atheta) fungicola (Thomson) new to the Finnish fauna (Coleoptera, Staphylinidae) ......... 1

Silfverberg, H.: Apion meieri Desbrochers des Loges in Finland (Coleoptera, Apionidae)

Silfverberg, H.: Cidnopus pilosus (Leske) and Agriotes sputator (Linnaeus) deleted from the Finnish fauna (Coleoptera, Elateridae)
Silfverberg, H.: Sphaeridium marginatum Fabricius in Finland (Coleoptera, Hydrophilidae) ..................... 3

Väisänen, R. \& Biström, O.: Pachyneura fasciata Zetterstedt found at Saarijärvi, Central Finland (Diptera, Pachyneuridae)

Viitasaari, M.: Nematus tulunensis Vikberg new to the Finnish fauna (Hymenoptera, Tenthredinidae) ....... 4

Vikberg, V.: Diaspidiotus bavaricus Lindinger (Diaspididae) and Acanthococcus baldonensis Rasina (Eriococcidae) new to the Finnish fauna 4

\section{Literature reviews}

Alford, D. V.: A colour atlas of pests of ornamental trees, shrubs and flowers. (U. Carlberg) ........................ 174

Engels, W. (ed.): Social insects. An evolutionary approach to castes and reproduction. (I. Teräs) .................... 190

Fujii, K., Gatehouse, A. M. R., Johnson, C. D., Mitchell, R. \& Yoshida, T. (eds.): Bruchids and legumes: economics, ecology and coevolution. (H. Silfverberg) 78

Gilbert, F. (ed.): Insect life cycles: genetics, evolution and co-ordination. (P. Pamilo) .................................. 210

Gilbert, L. I. \& Miller, T. A. (eds.): Immunological techniques in insect biology. (C. Roos) ..................... 229

Gilbert, P. \& Hamilton, C. J.: Entomology: a guide to information sources. (H. Silfverberg) ................... 156

Hodgson, E. \& Kuhr, R. J. (eds.): Safer insecticides. Development and use. (S. Turunen) ........................ 227

Matile, L.: Recherches sur la systématique et l'évolution des Keroplatidae (Diptera, Mycetophiloidea). (W. Hackman) .. 44

Spencer, K. A.: Host specialization in the World Agromyzidae (Diptera). (A. Albrecht) ................. 192

Stavenga, D. G. \& Hardie, R. C. (eds.): Facets of vision. (K. Donner) 111

Steinmann, H.: World catalogue of Dermaptera. (L. Huldén) 228

Stork, N. E. (ed.): The role of ground beetles in ecological and environmental studies. (O. Biström) ............ 110

Watt, A. D., Leather, S. R., Hunter, M. D. \& Kidd, N. A. C. (eds.): Population dynamics of forest insects. (J. Selander). 